$\begin{array}{lccc}\text { POLISH JOURNAL } & \text { OF } & \text { SOIL } & \text { SCIENCE } \\ \text { VOL. LIII/1 } & 2020 & \text { PL ISSN 0079-2985 }\end{array}$

DOI: $10.17951 / \mathrm{pjss} / 2020.53 .1 .149$

\author{
ADEL GHONEIM*, MOHAMMED S. AL-SAKKAF*, \\ ABDULLAH S. MODAIHSH*, KHALED D. ALOTAIBI*, \\ SAIFF ALHARBI**, SAMI A. ALDHUMRI***
}

\title{
SOIL PHOSPHORUS FRACTIONATION IN CALCAREOUS SOIL AS AFFECTED BY ORGANIC AMENDMENTS APPLICATION
}

Received: 24.09 .2019

Accepted: 17.03.2020

Abstract. Understanding of $\mathrm{P}$ transformations following organic amendments addition to highly calcareous soils is necessary for developing better management practices that can help enhance $P$ fertilizer use efficiency. Phosphorus solubility and availability for plant uptake under the conditions of arid calcareous soil is very low, making $\mathrm{P}$ nutrient supply a critical issue under these conditions. The aim of this study was to evaluate the impact of various types of organic amendments (chicken compost, cow compost and a mixture of humic-fulvic acid) applied alone at different rates of $\mathrm{KH}_{2} \mathrm{PO}_{4}$ fertilizer on $\mathrm{P}$ fractions in calcareous soil using the sequential chemical extraction method. Amended calcareous soil was incubated under laboratory conditions and soil samples were collected at $0,4,8$ and 16 weeks of the incubation periods. Soil was sequentially extracted and analyzed for $\mathrm{P}$ different fractions. The results indicated that the addition of chicken and cow compost increased soluble and exchangeable-P and Ca-P fractions in calcareous soil and the increases depend on application rates. The results indicated that combination of chicken and cow compost with different $\mathrm{KH}_{2} \mathrm{PO}_{4}$ fertilizer application rates increased the concentration of soluble and exchangeable-P in the soil compared to organic amendments or $\mathrm{KH}_{2} \mathrm{PO}_{4}$ fertilizer applied alone. The $\mathrm{P}$ associated with $\mathrm{Ca}$ was the dominant $\mathrm{P}$ fractions in soil, ranging between 51 to $59 \%$ regardless of the different treatment and the period of incubations. The Al- and Fe-associated $\mathrm{P}$

* Department of Soil Sciences, College of Food and Agricultural Sciences, King Saud University, 2460 Riyadh, 11451, Saudi Arabia.

** King Abdulaziz City for Science and Technology, 6086 Riyadh, 11442, Saudi Arabia.

*** Department of Biology, Alkhormah University College, Taif University, 21974, Saudi Arabia. Corresponding author's e-mail: adelrrtc.ghoneim@gmail.com 
fractions varied between 2 and $9 \%$, with the maximum value being observed at the eighth week of incubation. The residual-P fraction ranged between 5 and $22 \%$ at different incubation periods.

Keywords: changes in P fractions, mineral fertilizers, organic fertilizers, sequential fractionation, soils

\section{INTRODUCTION}

Phosphorus $(\mathrm{P})$ use efficiency and recovery is extremely low in agricultural soils of Saudi Arabia (Ahmad et al. 2018). This is related to the high content of free $\mathrm{CaCO}_{3}$ in those soils. After $\mathrm{P}$ fertilizer is added to a calcareous soil, $\mathrm{P}$ undergoes a series of chemical reactions with $\mathrm{Ca}$ to form $\mathrm{Ca}$-associated $\mathrm{P}$ forms that are of low solubility and availability for plant (Alharbi et al. 2018). The soils of Saudi Arabia are also characterized by their very low content of organic matter and coarse texture, and those factors have a negative impact on P fertilizer use efficiency. The utilization of $\mathrm{P}$ by plants is generally very low due to the fixation and adsorption of $\mathrm{P}$ by soils (Al Harbi et al. 2013, Al-Rohily et al. 2013). This results sometimes in excessive use of $\mathrm{P}$ fertilizers with low $\mathrm{P}$ recovery. The main source of $\mathrm{P}$ fertilizers is via mining rock phosphate, a non-renewable resource whose reserve is subject to depletion under the current excessive use of P fertilizers. The global phosphate reserves range typically in the order of a few hundred years (Dawson and Hilton 2011, European Commission 2013). However, the good quality rock phosphate has been estimated to be depleted in the next 80 years if extraction continues at the current rate (Smil 2000). The decline in the quality of rock phosphate will cause the cost of P extraction to increase (Smil 2004).

The addition of organic manure not only provides additional sources of nutrients, but improves the soil physical and chemical conditions and may increase the efficiency of added P fertilizers (Zhu et al. 2018). Information on the availability of $\mathrm{P}$ following chemical fertilizer and compost application to the soil may improve the management of $\mathrm{P}$ fertilization (Al Harbi et al. 2013). Time is the major factor for $\mathrm{P}$ transformations in the soil and available P. For example, after the rapid decomposition of applied organic materials to the soil, the available $\mathrm{P}$ will increase, and more stable $\mathrm{P}$ fractions could remain in the soil. In a soil incubation study, Kashem et al. (2004) found that the application of swine manure caused an initial increase of the water-extractable P fraction, but after 16 weeks of incubation, the water-extractable $\mathrm{P}$ fraction decreased with the simultaneous increase of the $\mathrm{P}-\mathrm{NaHCO}_{3}$ fraction. Moreover, the application of cattle manure decreased available $\mathrm{P}$, whereas other more stable $\mathrm{P}$ fractions increased, which suggests that microorganisms transformed inorganic available $\mathrm{P}$ into an organic form because of the higher amount of organic residue in the manure.

Information on the $\mathrm{P}$ availability following chemical fertilizer and organic fertilizer application to soil may improve the management of $\mathrm{P}$ fertilization. 
Mahmoud et al. (2019) found that the application of biochar with inorganic P can be a promising strategy to improve soil productivity and soil quality in alkaline soil.

Application of organic amendments in combination with P fertilizers to calcareous soils of Saudi Arabia is not a common practice. Such studies on using local organic amendments to increase $\mathrm{P}$ solubility in calcareous soils receiving $\mathrm{P}$ fertilizers are needed. This can help better understand $\mathrm{P}$ transformations and solubility and therefore improve P fertilizer use efficiency under such conditions. Therefore, the objective of this study was to evaluate the effectiveness of the addition of chicken compost, cow compost, and mixture of humic-fulvic acids with different application rate of $\mathrm{KH}_{2} \mathrm{PO}_{4}$ fertilizer on $\mathrm{P}$ fractions in calcareous soils. The effect of the period of incubation on the P species was also evaluated.

\section{MATERIALS AND METHODS}

\section{Soil sampling}

Soil samples was collected from the surface layers $(0-30 \mathrm{~cm})$ of calcareous soils located in the research center of King Saud University in Riyadh, Saudi Arabia. The soil samples were air-dried, ground, and sieved through a 2-mm sieve. Physical and chemical properties of the soil and $\mathrm{P}$ fractionation of the original soil are shown in Table 1.

\section{Types of organic materials}

Three organic fertilizers were used to evaluate their effectiveness on $\mathrm{P}$ availability and changes in $\mathrm{P}$ fractions in calcareous soils. These organic fertilizers included chicken compost, cow compost, and a mixture of humic-fulvic acids with different application rates of chemical-P fertilizers. The chemical characteristics of these organic fertilizers are shown in Table 2.

\section{Incubation study}

The incubation experiment was conducted at the Soil Science Department, College of Food and Agricultural Sciences, King Saud University, Saudi Arabia. The soil incubation experiment was conducted in glass jars with $300 \mathrm{~g}$ soil capacity. Chicken compost, cow compost, and a mixture of humic and fulvic acids with different application rates of chemical-P fertilizer were used (12 treatments) in a completely randomized design (CRD) with three replicates. The glass jars were incubated at $25^{\circ} \mathrm{C}$ and $70 \%$ of field capacity. Represented subsoil samples were collected from each treatment at $0,2,4,8$, and 16 weeks after incubation and analyzed for P sequential fractionation. 

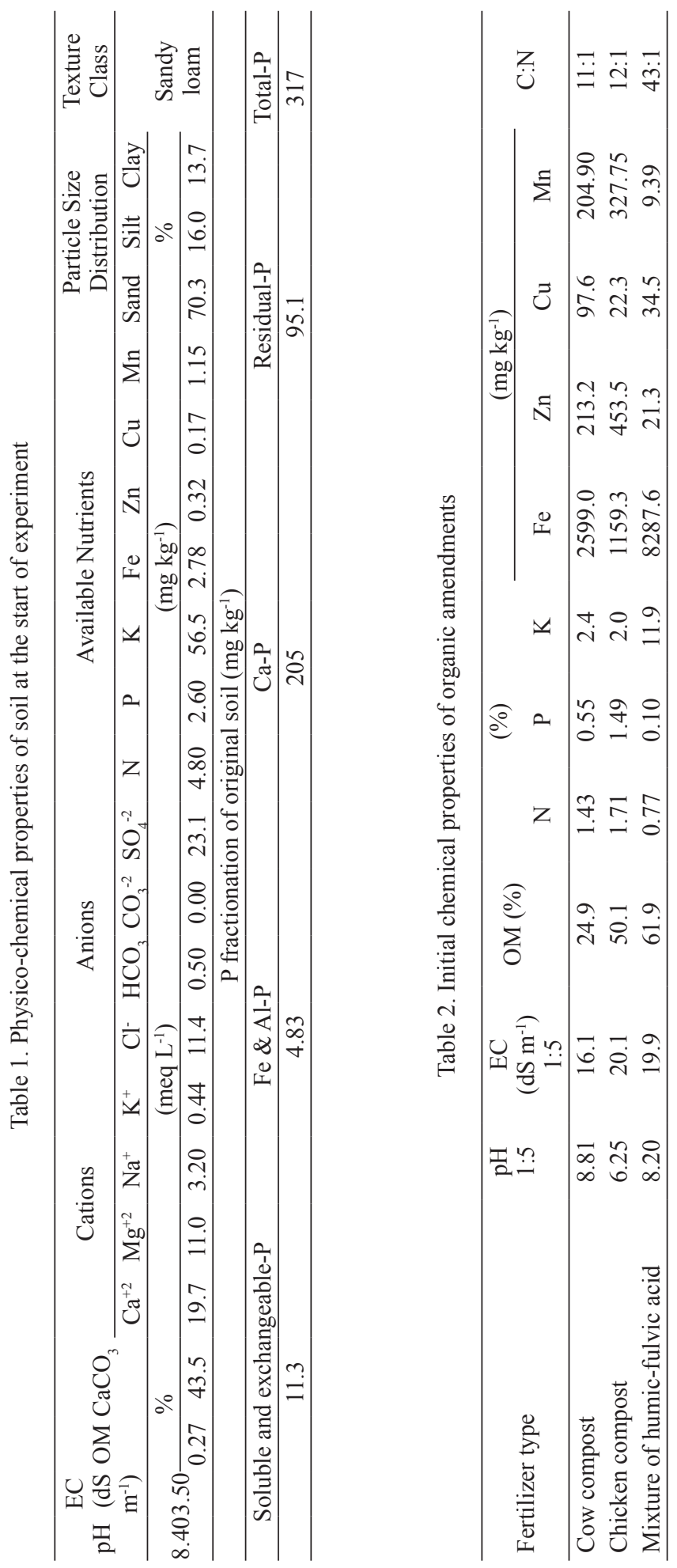


\section{Sequential P fractionation}

A sequential P fractionation method reported by Hedley et al. (1982) with a slight modification, as described by Tiessen and Moir (1993) was used. Briefly, a $1.0 \mathrm{~g}$ soil sample was extracted with $25 \mathrm{~mL}$ of $\mathrm{NaHCO}_{3} 0.50 \mathrm{M}$ solution, shaken for $16 \mathrm{~h}$, and centrifuged at $4000 \mathrm{rpm}$ for $10 \mathrm{~min}$ to extract soluble and exchangeable-P, while the remaining soil sample was saved for subsequent extractions. The $\mathrm{P}$ bound to $\mathrm{Al}$ and $\mathrm{Fe}$ hydroxide minerals were extracted by adding $25 \mathrm{~mL}$ of $0.10 \mathrm{M} \mathrm{NaOH}$ solution to the soil sample from the previous extraction and shaken for $16 \mathrm{~h}$. The solution was then centrifuged at $4000 \mathrm{rpm}$ for 5 min and analyzed for $\mathrm{Fe}$ and $\mathrm{Al}$ phosphate. The Ca-bound $\mathrm{P}$ was extracted by adding $25 \mathrm{~mL}$ of $1.0 \mathrm{M} \mathrm{HCl}$ to the soil sample and shaken for $16 \mathrm{~h}$. The supernatant was then centrifuged at $4000 \mathrm{rpm}$ for $5 \mathrm{~min}$ and analyzed for $\mathrm{Ca}$ phosphate. The residual $\mathrm{P}$ was digested by adding $10 \mathrm{~mL}$ of concentrated $\mathrm{HNO}_{3}$ to the soil sample.

\section{Statistical analysis}

Data were analyzed using SAS Version 9.4 (SAS Institute, 2013) and means were compared by Duncan's multiple range test (DMRT) with a 5\% probability.

\section{RESULTS AND DISCUSSION}

\section{Properties of soil and organic fertilizers}

The physical and chemical properties of soils used in this study are listed in Table 1. The soil texture was sandy loam and the soil $\mathrm{pH}$ was 8.40 with EC of $3.50 \mathrm{dS} \mathrm{m}^{-1}$. Additionally, the results indicated that the percentage of $\mathrm{CaCO}_{3}$ was relatively high, which is considered the most critical factor to fix $\mathrm{P}$ as calcium phosphate, which will not be available for plant uptake. As a result, sequential extraction of soil $\mathrm{P}$ significantly varied where the largest $\mathrm{P}$ fraction was $\mathrm{Ca}-\mathrm{P}$ followed by soluble and exchangeable-P and Fe and Al-P (Table 1). Furthermore, Table 2 shows chemical characteristics of evaluated organic fertilizers. The results indicated that $\mathrm{pH}$ was $8.20,6.30$, and 8.80 for chicken compost, cow compost, and the mixture of humic and fulvic acid, respectively, and the percentage of organic matter (OM) content was 24.9, 50, and 61.9 for chicken compost, cow compost, and the mixture of humic and fulvic acid, respectively. 


\section{Influence of addition of organic fertilizers on P fractions}

The dissolution of organic fertilizers in soil had a significant impact on soil properties, including the soil $\mathrm{pH}$ and $\mathrm{P}$ fractions. Tables 3 and 4 show the effects of different treatments and incubation periods on $\mathrm{P}$ fractions, which include the soluble and exchangeable-P, $\mathrm{Al}$ and $\mathrm{Fe}$-bound $\mathrm{P}, \mathrm{Ca}$-bound $\mathrm{P}$, and residual-P as discussed below.

\section{Soluble and exchangeable-P}

Table 3 shows $P$ fractions as influenced by organic fertilizers with different rates of $\mathrm{KH}_{2} \mathrm{PO}_{4}$ fertilizer, as well as different times of incubation. At zero time of incubation, the treatment of cow compost $(10 \mathrm{~g})$ with $\mathrm{KH}_{2} \mathrm{PO}_{4}$ fertilizer (100 g) and $\mathrm{KH}_{2} \mathrm{PO}_{4}$ fertilizer $(300 \mathrm{~g})$ exhibited the highest concentration of soluble and exchangeable-P extracted by $\mathrm{NaHCO}_{3}$ compared to that of the control treatment. Furthermore, the $2^{\text {nd }}$ highest concentration of soluble and exchangeable-P was observed for the treatment of chicken compost $(10 \mathrm{~g})$ and chicken compost $(10 \mathrm{~g})$ with $\mathrm{KH}_{2} \mathrm{PO}_{4}$ fertilizer $(100 \mathrm{~g})$ compared to that of other treatments. Similar results were obtained at 4 weeks of incubation when the highest concentration of soluble and exchangeable-P was recorded for chicken compost $(10 \mathrm{~g}$ $\mathrm{kg}^{-1}$ ) with $\mathrm{KH}_{2} \mathrm{PO}_{4}$ fertilizer ( $300 \mathrm{~g}$ ) compared to that of the control treatment, whereas there were no significant differences among the chicken compost $(10 \mathrm{~g}$ $\left.\mathrm{kg}^{-1}\right)$, the $\mathrm{KH}_{2} \mathrm{PO}_{4}$ fertilizer $\left(100 \mathrm{mg} \mathrm{P} \mathrm{kg}{ }^{-1}\right)$, and the $\mathrm{KH}_{2} \mathrm{PO}_{4}$ fertilizer (300 $\mathrm{mg}$ $\left.\mathrm{P} \mathrm{kg}^{-1}\right)$. At 8 weeks of incubation, the treatments of cow compost $\left(10 \mathrm{~g} \mathrm{~kg}^{-1}\right)+$ $\mathrm{KH}_{2} \mathrm{PO}_{4}$ fertilizer $\left(300 \mathrm{mg} \mathrm{P} \mathrm{kg}{ }^{-1}\right)$ and chicken compost $\left(10 \mathrm{~g} \mathrm{~kg}^{-1}\right)+\mathrm{KH}_{2} \mathrm{PO}_{4}$ fertilizer (300 $\left.\mathrm{mg} \mathrm{P} \mathrm{kg}^{-1}\right)$ had the highest concentration of soluble and exchangeable-P compared to that of the control treatment. At 16 weeks of incubation, there were significant differences between organic fertilizers; the highest concentrations of soluble and exchangeable-P were recorded for the cow compost $\left(10 \mathrm{~g} \mathrm{~kg}^{-1}\right)+\mathrm{KH}_{2} \mathrm{PO}_{4}$ fertilizer $\left(300 \mathrm{mg} \mathrm{P} \mathrm{kg}{ }^{-1}\right)$ treatment.

On the other hand, Fig. 1 shows the proportions of $\mathrm{P}$ fractions during different incubation periods. The results showed that the addition of organic fertilizers increased the concentration of soluble and exchangeable-P. This increase is caused by the decomposition of organic materials, which produced organic acids that could solubilize and release P from insoluble phosphate minerals and reduce the $\mathrm{P}$ adsorption to soil particles. This is consequently expected to increase $\mathrm{P}$ availability in the soil, whereas decomposed organic matter has been reported to decrease $\mathrm{P}$ adsorption and enhance $\mathrm{P}$ availability (Sánchez-de Prager and Cisneros-Rojas 2017); therefore, application of organic fertilizers with $\mathrm{KH}_{2} \mathrm{PO}_{4}$ fertilizer may be a promising management option to enhance the availability and solubility of applied $\mathrm{P}$ fertilizers. These results are consistent with those of another study, which confirmed that applying organic materials 


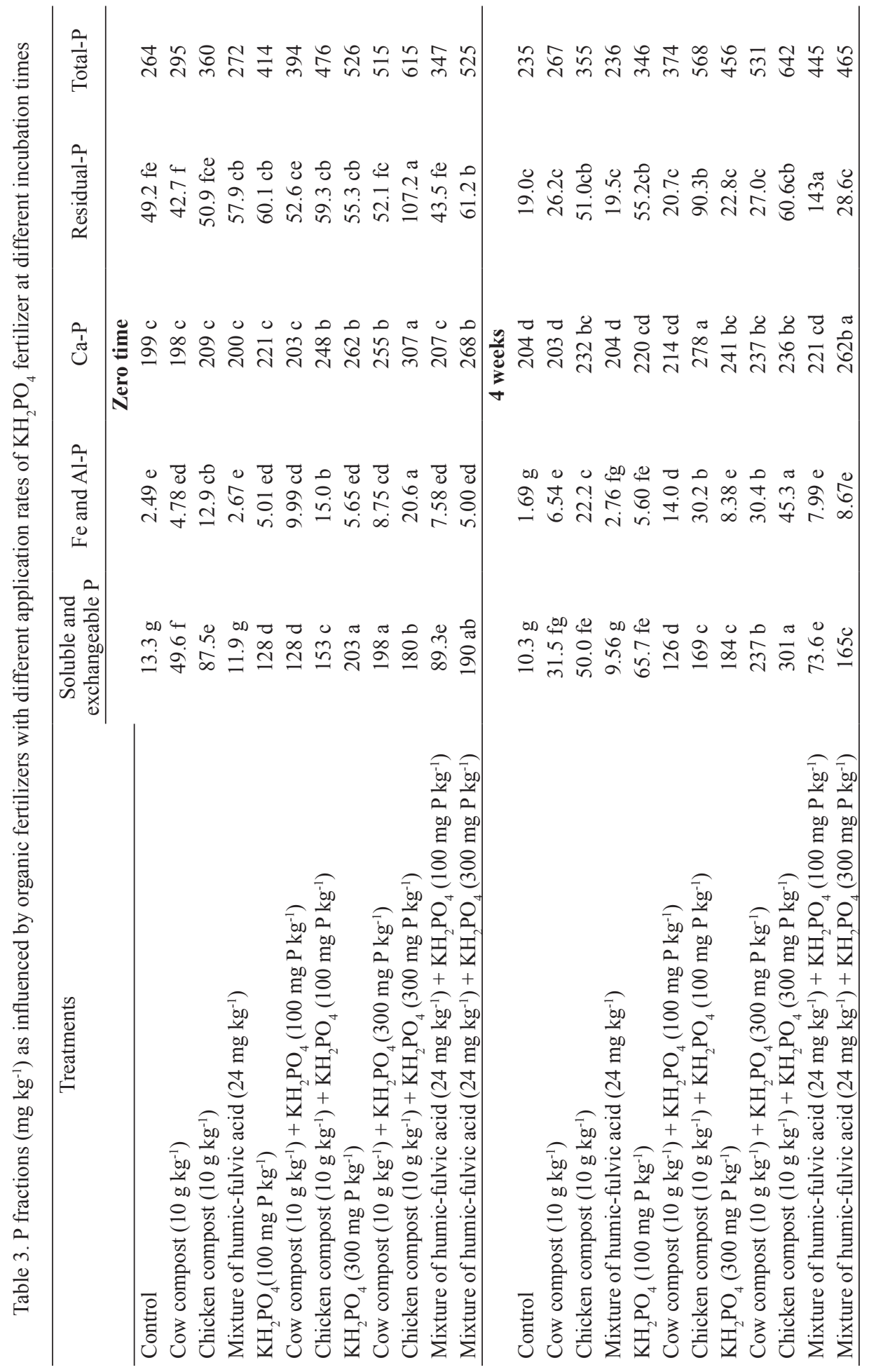




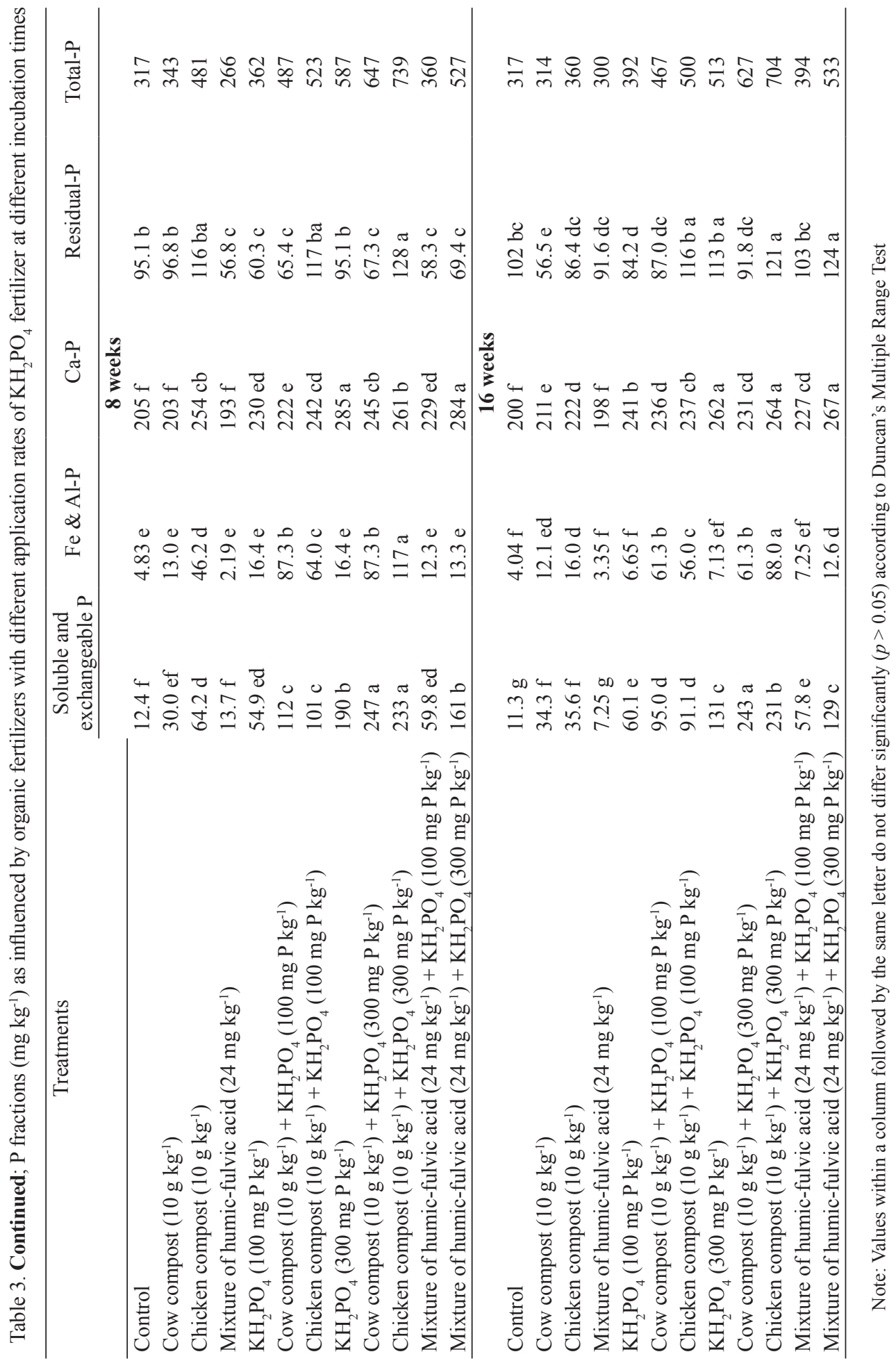




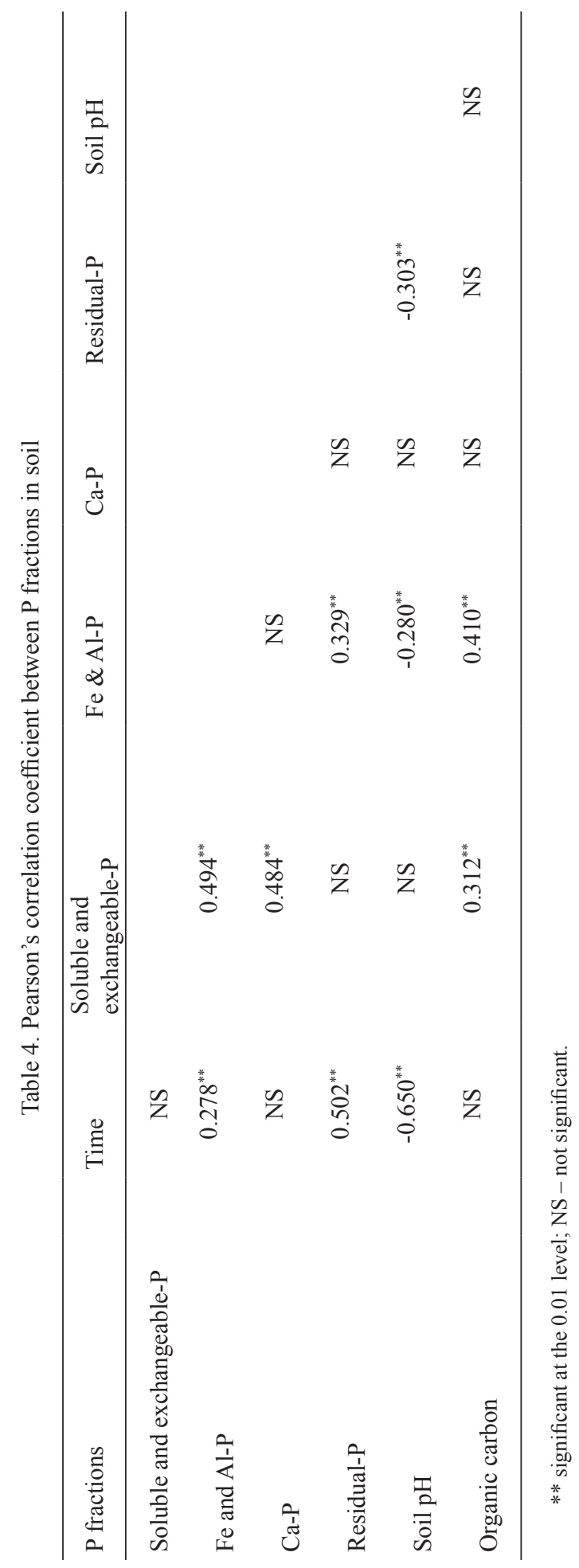


increased the concentration of soluble and exchangeable-P as the incubation time increased (Yu et al. 2013). These results are also in agreement with the findings of Kashem et al. (2004), who documented that the concentration of the $\mathrm{P}$ fractions extracted by $\mathrm{NaHCO}_{3}$ increased with increasing incubation time.

\section{Al-Fe bound P}

Table 3 shows that there were significant differences between organic fertilizers and the concentration of Al-Fe bound $\mathrm{P}$ extracted by $\mathrm{NaOH}$. At zero time of incubation, the maximum concentration of Al-Fe bound $\mathrm{P}$ was observed in the chicken compost $\left(10 \mathrm{~g} \mathrm{~kg}^{-1}\right)$ and $\mathrm{KH}_{2} \mathrm{PO}_{4}$ fertilizer $\left(300 \mathrm{mg} \mathrm{P} \mathrm{kg}^{-1}\right)$ treatment compared to the control treatment. Likewise, at 4 weeks of incubation, the chicken compost $\left(10 \mathrm{~g} \mathrm{~kg}^{-1}\right)$ and $\mathrm{KH}_{2} \mathrm{PO}_{4}$ fertilizer $\left(300 \mathrm{mg} \mathrm{P} \mathrm{kg}^{-1}\right)$ treatment had the highest concentration of Al-Fe associated with $\mathrm{P}$. Similar results were obtained at 16 weeks of incubation when the highest concentration was recorded for the chicken compost $\left(10 \mathrm{~g} \mathrm{~kg}^{-1}\right)+\mathrm{KH}_{2} \mathrm{PO}_{4}$ fertilizer $\left(300 \mathrm{mg} \mathrm{P} \mathrm{kg}^{-1}\right)$ treatment.

Otherwise, Fig. 1 shows the ratio of Al-Fe bound $\mathrm{P}$ during different incubation periods; the results demonstrated that the ratio of this $\mathrm{P}$ fractions ranged from 2 to $8 \%$ of total $\mathrm{P}$, regardless of the treatment or incubation periods. The results indicated that the amounts of the Al-Fe P fractions were very low compared to other $\mathrm{P}$ fractions. This was likely caused by the high original concentration of $\mathrm{Ca}$ ions in the soil, which was responsible for determining the ion speciation in the soil solution (Bohn et al. 2001). Moreover, the high concentration of $\mathrm{CaCO}_{3}$ is broadly known to be the critical factor to fix $\mathrm{P}$ as Ca- phosphate as observed in this study.

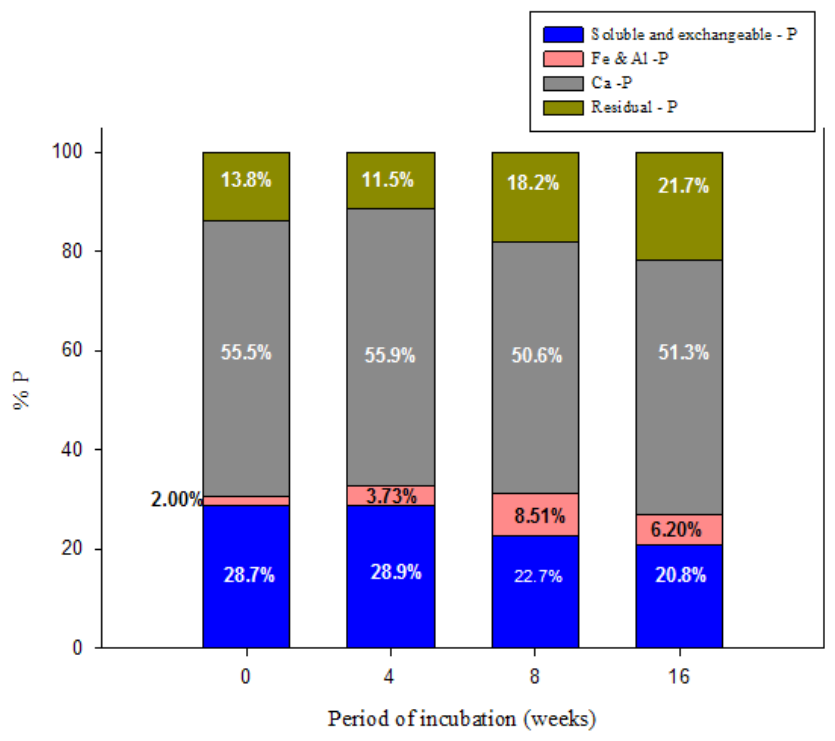

Fig. 1. Percentage of different $P$ fractions during incubation periods 


\section{Ca-bound P}

The results of this study showed significant effects of organic fertilizers on Ca-bound $\mathrm{P}$, which is considered highly insoluble for plant uptake and has been documented to be the dominant $P$ fraction in calcareous soil (Shen et al. 2004). As is shown in Table 3, Ca-bound $\mathrm{P}$ was the highest concentration at zero-time of incubation for the chicken compost $\left(10 \mathrm{~g} \mathrm{~kg}^{-1}\right)$ and $\mathrm{KH}_{2} \mathrm{PO}_{4}$ fertilizer $(300 \mathrm{mg}$ $\mathrm{kg}^{-1}$ ) treatment. Additionally, at 4 weeks of incubation, the chicken compost (10 $\left.\mathrm{g} \mathrm{kg}^{-1}\right)+\mathrm{KH}_{2} \mathrm{PO}_{4}$ fertilizer $\left(100 \mathrm{mg} \mathrm{kg}^{-1}\right)$ treatment produced the highest concentration of Ca-bound $\mathrm{P}$ with a concentration of $278 \mathrm{mg} \mathrm{kg}^{-1}$, whereas the control treatment produced the lowest concentration. While, at 8 weeks of incubation, Ca-bound $\mathrm{P}$ had the highest concentration in the $\mathrm{KH}_{2} \mathrm{PO}_{4}$ fertilizer $(300 \mathrm{mg} \mathrm{P}$ $\left.\mathrm{kg}^{-1}\right)$ treatment followed by the chicken compost $\left(10 \mathrm{~g} \mathrm{~kg}^{-1}\right)+\mathrm{KH}_{2} \mathrm{PO}_{4}$ fertilizer (300 mg P kg${ }^{-1}$ ) treatment with concentrations of 285 and $261 \mathrm{mg} \mathrm{kg}^{-1}$, respectively. The same results were obtained at 16 weeks of incubation, when the highest concentration of Ca-bound $\mathrm{P}$ was recorded for the $\mathrm{KH}_{2} \mathrm{PO}_{4}$ fertilizer $(300 \mathrm{mg}$ $\left.\mathrm{P} \mathrm{kg}^{-1}\right)$ and chicken compost $\left(10 \mathrm{~g} \mathrm{~kg}^{-1}\right)+\mathrm{KH}_{2} \mathrm{PO}_{4}$ fertilizer $\left(300 \mathrm{mg} \mathrm{P} \mathrm{kg}{ }^{-1}\right)$ treatments. Regarding the percentage of $\mathrm{P}$ fractions listed in Fig. 1, Ca-bound $\mathrm{P}$ is the most common P fraction, ranging from 50 to $58 \%$ of total-P, regardless of other treatments or incubation periods. The maximum percentage of Ca-P was observed in comparison with other $\mathrm{P}$ fractions, which resulted in the highest concentration of $\mathrm{CaCO}_{3}$ under the conditions of this experiment. This supports the earlier observations that most Saudi Arabia soils are dominated by the Ca-P fraction (Alharbi et al. 2018, Rohily et al. 2019). However, the ratio of this $P$ fractions slightly decreased after 8 and 16 weeks of incubation. This decrease was caused by the decomposition of the added organic materials that could have produced organic acids and regulated the soil $\mathrm{pH}$.

\section{Residual-P}

Table 3 presents the concentration of residual-P at the different incubation periods as affected by organic fertilizers with varying rates of $\mathrm{KH}_{2} \mathrm{PO}_{4}$ fertilizer. At zero time of incubation, the residual- $\mathrm{P}$ was at its highest concentration for the chicken compost $\left(10 \mathrm{~g} \mathrm{~kg}^{-1}\right)$ with $\mathrm{KH}_{2} \mathrm{PO}_{4}$ fertilizer $\left(300 \mathrm{mg} \mathrm{P} \mathrm{kg}^{-1}\right)$ treatment with a concentration of $107 \mathrm{mg} \mathrm{kg}^{-1}$, whereas the treatment of cow compost (10 $\mathrm{g} \mathrm{kg}^{-1}$ ) produced the lowest concentration compared to that of other treatments. At 4 weeks of incubation, the highest concentration of residual-P was recorded for the mixture of humic and fulvic acid $\left(24 \mathrm{mg} \mathrm{kg}^{-1}\right)+\mathrm{KH}_{2} \mathrm{PO}_{4}$ fertilizer (300 $\left.\mathrm{mg} \mathrm{P} \mathrm{kg}{ }^{-1}\right)$ followed by the chicken compost $\left(10 \mathrm{~g} \mathrm{~kg}^{-1}\right)+\mathrm{KH}_{2} \mathrm{PO}_{4}$ fertilizer (100 $\mathrm{mg} \mathrm{P} \mathrm{kg}^{-1}$ ) treatment; however, there were no significant differences among the mixture of humic and fulvic acid $\left(24 \mathrm{mg} \mathrm{kg}^{-1}\right)$, cow compost $\left(10 \mathrm{~g} \mathrm{~kg}^{-1}\right)$, and cow compost $\left(10 \mathrm{~g} \mathrm{~kg}^{-1}\right)$ with $\mathrm{KH}_{2} \mathrm{PO}_{4}$ fertilizer (100 and $300 \mathrm{mg} \mathrm{P} \mathrm{kg}^{-1}$ ) 
treatments compared to that of the control treatment. However, at 8 weeks of incubation, the chicken compost $\left(10 \mathrm{~g} \mathrm{~kg}^{-1}\right)+\mathrm{KH}_{2} \mathrm{PO}_{4}$ fertilizer $\left(300 \mathrm{mg} \mathrm{P} \mathrm{kg}^{-1}\right)$ treatment had the highest concentration of residual-P with a concentration of $128 \mathrm{mg} \mathrm{kg}^{-1}$; however, there were no significant differences between the chicken compost $\left(10 \mathrm{~g} \mathrm{~kg}^{-1}\right)+\mathrm{KH}_{2} \mathrm{PO}_{4}$ fertilizer (100 and $\left.300 \mathrm{mg} \mathrm{P} \mathrm{kg}^{-1}\right)$ and chicken compost $\left(10 \mathrm{~g} \mathrm{~kg}^{-1}\right)$ treatments. Similar results were obtained at 16 weeks of incubation when the highest concentration of residual-P was recorded for the chicken compost $\left(10 \mathrm{~g} \mathrm{~kg}^{-1}\right)+\mathrm{KH}_{2} \mathrm{PO}_{4}$ fertilizer $\left(300 \mathrm{mg} \mathrm{P} \mathrm{kg}^{-1}\right)$ treatment with a concentration of $121 \mathrm{mg} \mathrm{kg}^{-1}$. This observation indicated that chicken compost had significant superiority over cow compost. On the other hand, the percentage of residual-P fraction shown in Fig. 1, as expected, responded differently with different incubation times. The residual-P fraction ranged from 14 to $22 \%$ of total-P and increased with incubation time. The results also indicated that the percentage of residual-P fraction was the $3^{\text {rd }}$ most dominant $\mathrm{P}$ fractions after the percentage of soluble and exchangeable-P and Ca-P fractions.

Additionally, the results showed a highly significant effect between the residual-P fraction and $\mathrm{P}$ associated with Fe and Al-P (Table 4). This observation is consistent with other findings reported by Solomon et al. (2002), in which there was a significant correlation between the ratio of residual-P and $\mathrm{P}$ associated with $\mathrm{Al}$ and $\mathrm{Fe}$ oxides.

\section{Total-P}

The concentration of total-P ranged from $232 \mathrm{mg} \mathrm{P} \mathrm{kg}^{-1}$ to $739 \mathrm{mg} \mathrm{P} \mathrm{kg}{ }^{-1}$ soil and the solitary addition of chicken compost or cow compost in combination with $\mathrm{KH}_{2} \mathrm{PO}_{4}$ fertilizer increased the concentration of total-P (Table 3). The addition of cow compost or chicken compost resulted in the increase of most of the different $\mathrm{P}$ forms in the soil compared to the control treatment. Chicken compost $\left(10 \mathrm{~g} \mathrm{~kg}^{-1}\right)+\mathrm{KH}_{2} \mathrm{PO}_{4}$ fertilizer $\left(300 \mathrm{mg} \mathrm{P} \mathrm{kg}^{-1}\right)$ recorded the highest concentration of total-P compared to other different treatments.

\section{CONCLUSIONS}

The results revealed that the addition of chicken and cow compost dramatically increased different $\mathrm{P}$ fractions in calcareous soil and the increase was dependent on the type of organic fertilizer and application rate of $\mathrm{KH}_{2} \mathrm{PO}_{4}$ fertilizer. The soluble and exchangeable-P, Ca-occluded $\mathrm{P}$ fraction, and residual-P fractions were the most dominant $\mathrm{P}$ forms. The results also indicated that there were significant differences between the effects of different $\mathrm{P}$ treatments and periods of incubation on soluble and exchangeable-P, Ca-occluded $\mathrm{P}$ fraction, residual-P fraction, $\mathrm{Fe}$ and $\mathrm{Al}$-occluded $\mathrm{P}$ fraction, and total-P. There was no significant difference 
between the addition of cow or chicken compost with $\mathrm{KH}_{2} \mathrm{PO}_{4}$ fertilizer at the rate of $300 \mathrm{mg} \mathrm{P} \mathrm{kg}^{-1}$ soil. We recommend the addition of only $100 \mathrm{mg} \mathrm{P} \mathrm{kg}^{-1}$ soil as $\mathrm{KH}_{2} \mathrm{PO}_{4}$ fertilizer with cow compost or chicken compost.

\section{ACKNOWLEDGEMENTS}

This research was supported by the Research Center, College of Food and Agricultural Sciences, Deanship of Scientific Research, King Saud University, Riyadh, Saudi Arabia. The authors thank the Deanship of Scientific Research and RSSU at King Saud University for their technical support.

Conflict of interest: On behalf of all authors, the corresponding author states that there is no conflict of interest.

\section{REFERENCES}

[1] Ahmad, M., Ahmad, M., El-Naggar, A.H., Usman, A., Abduljabbar, A., Vithanage, M., Elfaki, J., Abdulelah, A.F., Al-Wabel, A.M., 2018. Aging effects of organic and inorganic fertilizers on phosphorus fractionation in a calcareous sandy loam soil. Pedosphere, 28: 873-83. DOI: 10.1016/S1002-0160(17)60363-1

[2] Al Harbi, S., Ghoneim, A., Modaihsh, A., Mahjoub, M., 2013. Effect of foliar and soil application of phosphorus on phosphorus uptake, use efficiency and wheat grain yield in calcareous soil. Journal of Applied Sciences, 13: 188-192. DOI: 10.3923/jas.2013.188.192

[3] Alharbi, K., Ghoneim, A., Ebid, A., El Hamshary, H., El-Newehy, H., 2018. Controlled release of phosphorous fertilizer bound to carboxymethyl starch-g-polyacrylamide and maintaining a hydration level for the plant. International Journal of Biological Macromolecules, 116: 224-231. DOI: 10.1016/j.ijbiomac.2018.04.182

[4] Al-Rohily, K., Ghoneim, A., Modaihsh, M., Mahjoub, M., 2013. Phosphorus availability in calcareous soil amend with chemical phosphorus fertilizer, cattle manure compost and sludge manure. International Journal of Soil Science, 8: 17-24. DOI:10.3923/ijss.2013.17.24.

[5] Rohily, K. Ghoneim, A., El-Hamshary, H., Modaihsh, A. 2019. Developed and Evaluation of Slow Release Phosphorus Fertilizer Using Mono-ammonium Phosphate and Di-ammonium Phosphate. International Research Journal of Pure and Applied Chemistry, 19(1): 1-15. DOI: 10.9734/irjpac/2019/v19i130103

[6] Bohn, H.L., McNeal, B.L., O’Connor, G.A., 2001. Soil Chemistry, $3^{\text {rd }}$ ed. New York: John Wiley \& Sons, Inc.

[7] Dawson, C.J., Hilton, J., 2011. Fertilizer availability in a resource-limited world: Production and recycling of nitrogen and phosphorus. Food Policy, 36: S14-S22.

[8] European Commission, 2013. Consultative Communication on the Sustainable Use of Phosphorus. Brussels, Belgium: EU Commission, 8.7.2013, COM, 517 Final.

[9] Hedley, M.J., Stewart, J., Chauhan, B., 1982. Changes in inorganic and organic soil phosphorus fractions induced by cultivation practices and by laboratory incubations. Soil Science Society of America Journal, 46: 970-976.

[10] Kashem, M.A., Akinremi, O.O., Racz, G.J., 2004. Phosphorus fractions in soil amended with organic and inorganic phosphorus sources. Canadian Journal of Soil Science, 84: 83-90. DOI: $10.4141 / \mathrm{S} 03-018$ 
[11] Mahmoud, E., Ibrahim, M., Abd El-Rahman, L., Khader, K. 2019. Effects of biochar and phosphorus fertilizers on phosphorus fractions, wheat yield and microbial biomass carbon in Vertic Torrifluvents. Communications in Soil Science and Plant Analysis, 50(3): 362-72. DOI: 10.1080/00103624.2018.1563103

[12] Sánchez-de Prager, M., Cisneros-Rojas, C.A., 2017. Organic acids production by rhizosphere microorganisms isolated from a Typic Melanudands and its effects on the inorganic phosphates solubilization. Acta Agronómica, 66: 241-247. DOI: 10.15446/acag.v66n2.56148

[13] SAS Institute. 2013. SAS Statistical Software v. 9.4. North Carolina: SAS Institute, Inc Cary.

[14] Shen, J., Li, R., Zhang, F., Fan, J., Tang, C., Rengel, Z., 2004. Crop yields, soil fertility and phosphorus fractions in response to long-term fertilization under the rice monoculture system on a calcareous soil. Field Crops Research, 86: 225-238. DOI: 10.1016/j.fcr.2003.08.013

[15] Smil, V., 2000. Phosphorus in the environment: natural flows and human interferences. Annual Review of Energy and the Environment, 25: 53-88. DOI: 10.1146/annurev.energy.25.1.53

[16] Smil, V., 2004. Phosphorus availability in the $21^{\text {st }}$ century: management of a nonrenewable resource. Phosphorus \& Potassium, 217: 25-31.

[17] Solomon, D., Lehmann, J., Mamo, T., Fritzsche, F., Zech, W., 2002. Phosphorus forms and dynamics as influenced by land use changes in the sub-humid Ethiopian highlands. Geoderma, 105: 21-48.

[18] Tiessen, H., Moir, J.O., 1993. Characterization of available P by sequential extraction. In M.R. Carter, E.G. Gregorich (Eds.), Soil Sampling and Methods of Analysis, $2^{\text {nd }}$ ed., CRC Press, Boca Raton, Florida, USA.

[19] Yu, W., Ding, X., Xue, S., Li, S., Liao, X., Wang, R., 2013. Effects of organic-matter application on phosphorus adsorption of three soil parent materials. Journal of Soil Science and Plant Nutrition, 13: 1003-1017. DOI: 10.4067/S0718-95162013005000079

[20] Zhu, J., Li, M., Whelan, M., 2018. Phosphorus activators contribute to legacy phosphorus availability in agricultural soils: A review. Science of the Total Environment, 612: 522-537. DOI: 10.1016/j.scitotenv.2017.08.095 